\title{
Cultivation of a Blue Marine Sponge, Xestospongia Sp. (C.F. Neopretrosia Sp.) in Hatchery as an Ornamental Species
}

\author{
Kieattisak $\mathrm{Y}^{1}$, Udomsak $\mathrm{D}^{2}$, Wattana $\mathrm{W}^{3}$ and Patchara $\mathrm{P}^{4 *}$ \\ ${ }^{1}$ Department of Agricultural Technology, Walailak University, Thailand \\ ${ }^{2}$ Department of Sciences, Walailak University, Thailand \\ ${ }^{3}$ Department of Aquaculture, Rajamangala University of Technology, Thailand \\ ${ }^{4}$ Department of Marine Science, Rajamangala University of Technology, Thailand
}

Submission: October 18, 2016 Published: November 10, 2017

"Corresponding author: Patchara Pedpradab, Department of Marine Science, Faculty of Sciences and Fishery Technology, Natural Resources and Environment Institute, Rajamangala University of Technology, Srivijaya, Trang Campus, Sikao District, Trang Province, 92150, Thailand, Email: ppedpradab@gmail.com

\begin{abstract}
The cultivation of a blue marine sponge, Xestospongia sp. (C.f. Neopretrosia sp.) to be a marine ornamental species was performed in hatchery for 35 days. It was cultured in water circulation close system with vertical long line rope method. The small pieces of sponge were cut out from mother colony and further cultured in three different container materials including, glass, polymeric form box and plastic containers. Experimental design was done by CRD and the analysis of variance was also calculated to compare mean values. The results showed the sponge cultured in glass container gave highest weigh $(5.76 \mathrm{~g})$ on the other hand, the lowest weight $(5.63 \mathrm{~g})$ was observed in plastic containers, but it was not statistically significant difference $(p>0.05)$. All chemicals and physico chemicals parameters of cultured water showed under toxic level. The high fluctuate temperature during the days of 21-34 result decreasing growth of sponge.
\end{abstract}

\section{Introduction}

Marine sponges are present in the lists of most wholesaler supplying livestock and marine aquarium hobbyist as ornamental species, due to a variety of their coloration and shaping intention [1]. Additionally, sponges can also be used as biofilter in marine aquarium and marine environment, because their whole body construct by complex water circulation chambers call aquiferous system where are the microorganisms habitation and trapping particulate materials. Marine sponge fishing has been documented in bathing sponge since 1913 and highest peak catch found in 2003 tending over-harvesting in 2006 $[2,3]$. Among higher demand, the increasing global awareness of negative impact of natural marine sponge's collection had led the fishermen to evaluate sustainable solution for this important fishery [3]. Up to date, there is no sponges production support marine aquarium trade [4].
Even through mariculture (it is synonymously for aquaculture and practice agriculture) is one of suitable method for sponge ornamental production, but it deals with several problems, particularly sea area encroaching, marine transport interruption and nutrients depletion surround environment [5]. Thus, land base cultivation is the alternative way for sponge production. In this article, we report the production of marine sponge, Xestospongia sp. (c.f. Neopretrosia sp., (Figure 1) in hatchery via continuous natural water flow out technic. With the brilliant blue color, it is attractively interesting to aquarium hobbyists as a new marine ornamental species which will be launched in the local market in Thailand. This sponge distributes both in Thai gulf and the Andaman Sea area. It has taxonomically classified as a member of class Demospongia, order Haplosclerida and family Petrosidae [3]. 


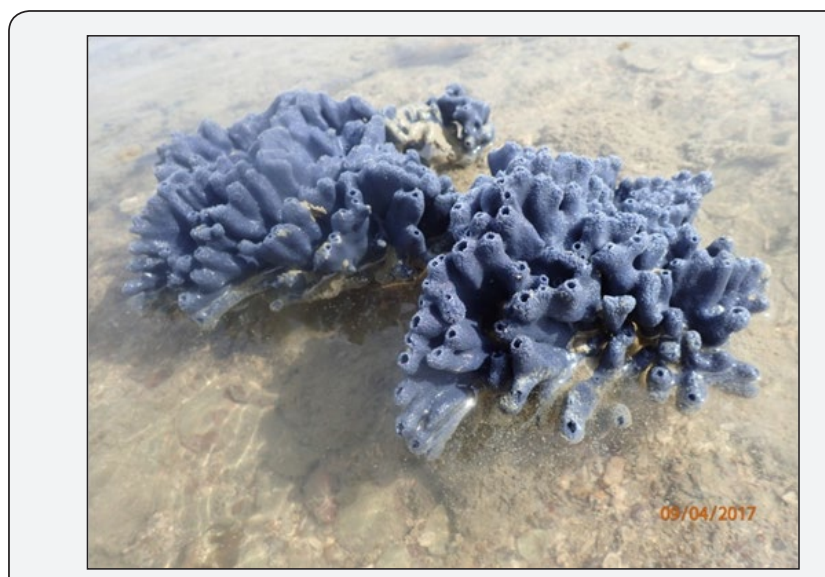

Figure 1: A blue marine sponge, Xestospongia sp. (c.f. Neopretrosia sp.).

\section{Material and Method}

\section{Animals preparation and experimental}

A design a sponge was collected in the Andaman Sea area, Southern of Thailand. It was kept in the preservation box in which control sea water temperature 27-29 oC during transferred to hatchery, and further recuperated in the water circulated marine aquarium pond for 10 days. Water circulation close system (Figure 2) was established for cultivation experiment containing 9 experimental units. Three different kinds of container materials (size $40 \mathrm{~cm} \times 50 \mathrm{~cm} \times 60 \mathrm{~cm}$ ) were used for a sponge culture including glass, plastic and polymeric form box. Experimental design performed by completely randomizes design (CRD) using two way ANOVA analysis to compare mean values. The vertical long line method was applied to each container. Sponge mother colony was cut in size $1 \times 2 \mathrm{~cm}$ a piece which was attached to a plastic sheet by nylon rope (Figure 3 ), individual rope contained 4 attached sheets. Four ropes were put in a cultural tank with 80 liters of sea water was filled.

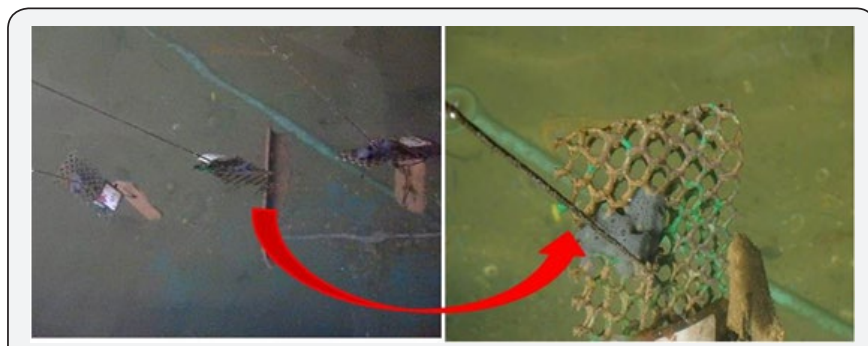

Figure 2: Long line cultural layout.

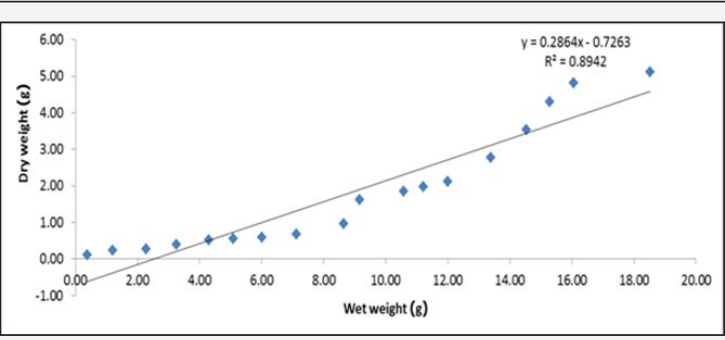

Figure 3 : The relationship curve of wet and dry weight a blue marine sponge, Xestospongia sp.

\section{Water quality measurement}

Water quality consist of temperature, DO, and pH measured by multi probe analyzer YSI 566 (New York, USA), salinity determined by reflecto salinometer (S-100 New York, USA), dissolve silicate in sea water analyzed by standard test kit (VISCOLOR, Macherey Nagel, Germany).

\section{Growth assessment}

Growth of sponges determined by wet weighing and converse to dry weigh by standard curve (Figure 4).

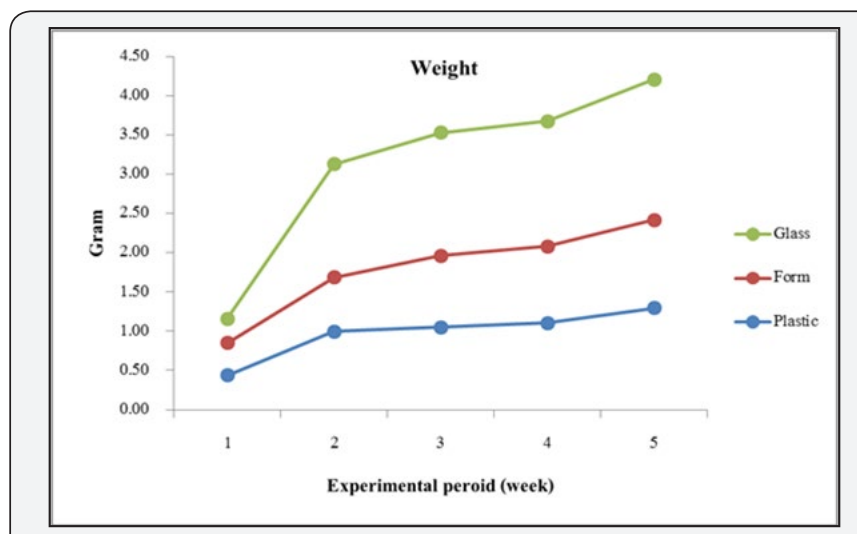

Figure 4 : Sponge growth curve in three different kinds of containers.

\section{Results and Discussion}

A sponge showed continuous higher weight during the experimental period (Figure 5). In three different kinds of cultivation containers, they gave the highest weigh in glass containers on the other hand, the lowest weigh had found in plastic containers. However, there are no statistically significant different of total weigh of sponge in all cultured container materials. This phenomenon can be explained by water temperature fluctuation in cultural condition. The water in plastic containers showed higher temperature than others during the period of days 21-30 (Figure 6). This high temperature results to stimulate germ cells developing that spends a lot of energy results to growing depletion. In addition, sponge cannot adapt to strong and rapid higher temperature fluctuation because cell components were damaged $[6,7]$.

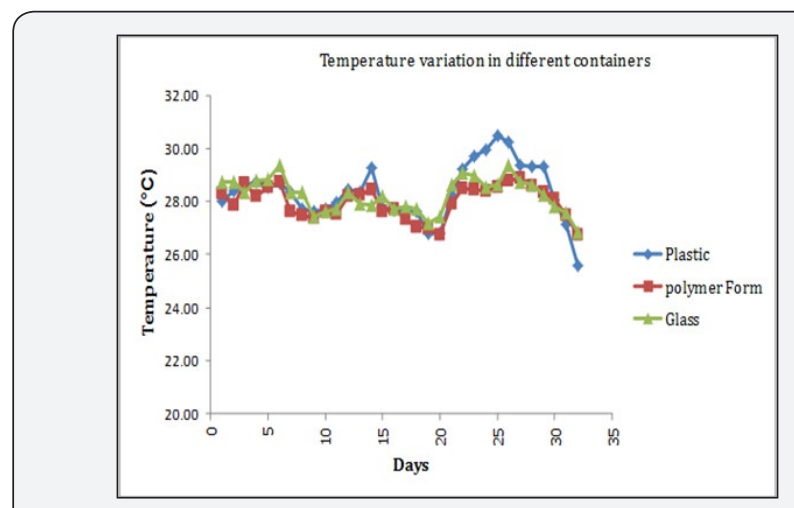

Figure 5 : Temperature of cultural water in different types of containers during experimental period. 


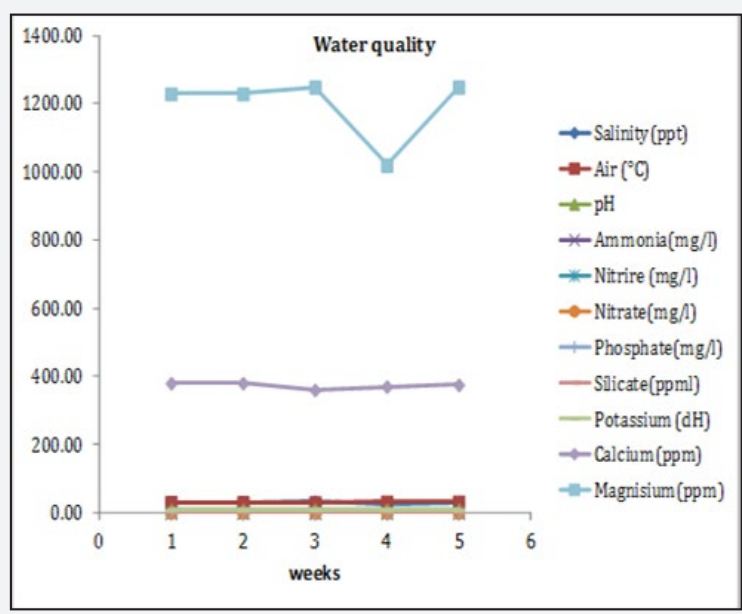

Figure 6 : Water quality analyzed during cultural period.(Many parameters overlapped at nearly the values of 0.00 ).

However, not just only temperature is affect to marine sponge growing, but there are also others environmental parameters including nitrite, nitrate, ammonia, phosphate, dissolve calcium, magnesium, pH and salinity [8]. In our study, we can control those of parameters were under toxic level as shown in (Figure 7) thus, only temperature was effected to growth of a blue marine sponge, Xestospongia sp.

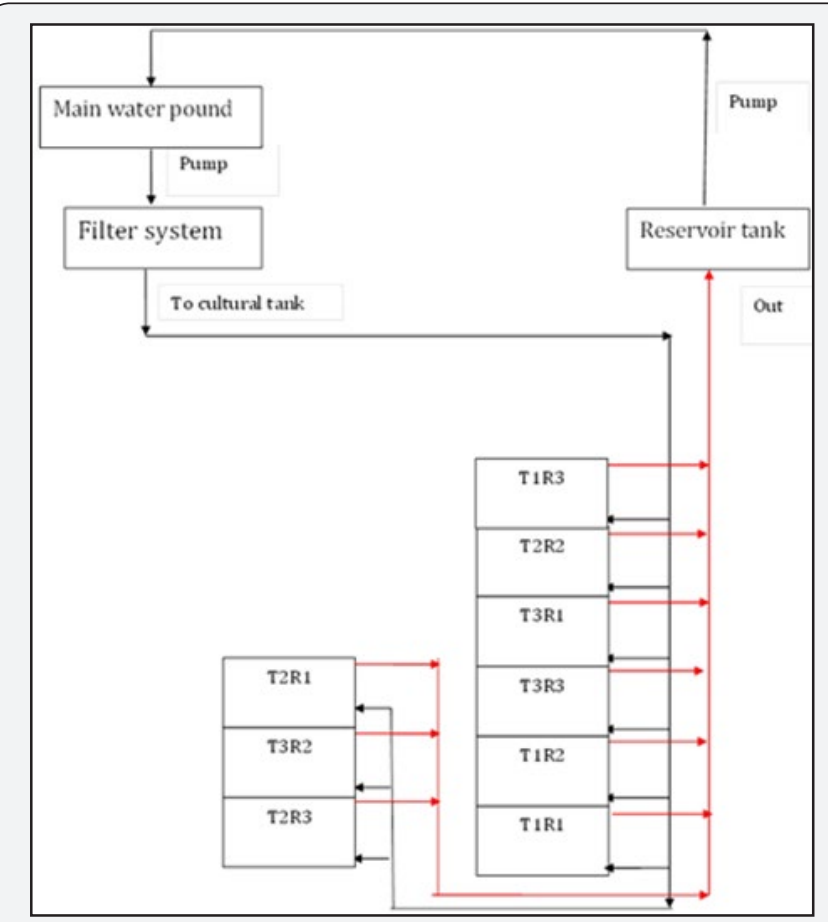

Figure 7 : Cultural system Remark: $\mathrm{T} 1=$ glass containers, $\mathrm{T} 2=$ plastic containers, $\mathrm{T} 3=$ polymer bubble boxes, $\mathrm{R}=$ replication
Table 1: Statistical analysis of sponge weight.

\begin{tabular}{|c|c|c|c|c|c|}
\hline Containers & N & Mean & SD & F & p-value \\
\hline $\begin{array}{c}\text { Polymer } \\
\text { form }\end{array}$ & 3 & 0.66 & 0.26 & 1.73 & 0.02 \\
\hline Glass & 3 & 1.21 & 0.59 & & \\
\hline Plastic & 3 & 0.8 & 0.09 & & \\
\hline
\end{tabular}

\section{Conclusion}

The cultivation of a blue marine sponge, Xestospongia sp. in circulated close system to be ornamental species is interesting and high possibly. Water parameters in cultural system should be strongly considered particularly water temperature fluctuation daily.

\section{Acknowledgement}

This work was supported in part by grant from Walailuk University (05/2560) and Rajamangala University of Technology Srivijaya (2560).

\section{References}

1. Tlusty M (2005) The benefits and risks of aqua cultural production for the aquarium trade. Aquaculture 205: 203-219.

2. Calado R (2006) Marine ornamental species from European waters: a valuable overlooked resource or a future threat for the conservation of marine ecosystems. Sci Mar 70(3): 389-398.

3. Sipkema D, Osinga R, Schatton W, Mendola D, Tramper J, et al. (2005) Large-scale production of pharmaceuticals by marine sponges: sea, cell, or synthesis. Biotechnol Bioeng 90(2): 201-202.

4. Osinga R, Tramper J, Wijffels RH (1999) Cultivation of Marine Sponges. Mar Biotechnol 1(6): 509-532.

5. Koopmans M, Wijffels RH (2008) Seasonal growth rate of the Sponge Haliclona oculata (Demospongiae: Haplosclerida). Mar Biotechnol 10(5): 502-510.

6. Hausmanna R, Vitello MP, Leitermanna F, Syldatk C (2006) Advances in the production of sponge biomass Aplysina aerophoba-A model sponge for ex situ sponge biomass production. J Biotechnol 124(1): 117-127.

7. Duckworth AR, West L, Vansach T, Stubler A, Hardt M (2012) Effects of water temperature and $\mathrm{pH}$ on growth and metabolite biosynthesis of coral reef sponges. Mar Ecol Prog Ser 462: 67-77.

8. Schiefenhovel K, Kunzmann A (2012) Sponge farming trials: survival, attachment, and growth of two Indo-Pacific sponges, Neopetrosia sp and Stylissa massa. J Mar Biol 2012: 1-11. 
This work is licensed under Creative Commons Attribution 4.0 License DOI:10.19080/ARTOAJ.2017.12.555838
Your next submission with Juniper Publishers will reach you the below assets

- Quality Editorial service

- Swift Peer Review

- Reprints availability

- E-prints Service

- Manuscript Podcast for convenient understanding

- Global attainment for your research

- Manuscript accessibility in different formats

( Pdf, E-pub, Full Text, Audio)

- Unceasing customer service

Track the below URL for one-step submission https://juniperpublishers.com/online-submission.php 